\title{
Parkinson's disease and essential tremor in families of patients with early-onset Parkinson's disease
}

\author{
REIJO J MARTTILA, URPO K RINNE \\ From the Department of Neurology, University of Turku, Turku, Finland
}

SUMMARY The occurrence of Parkinson's disease and of essential tremor was examined in the parents and siblings of 52 Parkinson's disease patients with onset before the age of 45 years. The expected numbers of cases with Parkinson's disease or essential tremor were calculated according to the age and sex specific incidence rates of Parkinson's disease and essential tremor in the general population. Among the parents, there was one case of Parkinson's disease (expected 1.2), and 10 cases of essential tremor (expected 5.4); among the siblings there were two cases of Parkinson's disease (expected $0 \cdot 7$ ), and three cases of essential tremor (expected 5.3). The observed and expected incidence of Parkinson's disease or essential tremor were not significantly different. This does not support the inheritance of early-onset Parkinson's disease, or the association of Parkinson's disease with essential tremor.

The contribution of heredity to Parkinson's disease has been evaluated using several approaches. The proportion of patients with other cases among relatives has varied between $2 \%$ and $62 \%$, permitting no firm conclusion as to whether heredity is involved or not. ${ }^{12}$ Comparing the occurrence of Parkinson's disease in the siblings of Parkinsonian patients and of their spouses has not indicated any significant difference. ${ }^{34}$ Similarly, there was no difference in the occurrence of Parkinson's disease in the relatives of patients compared with relatives of a matched control sample from the general population. ${ }^{5}$ In recent twin studies, concordance for Parkinson's disease in monozygotic twins has been very low. ${ }^{6-8}$ However, notwithstanding the general trend of these observations it has been suggested that among relatives of patients with early-onset Parkinson's disease there is a high occurrence of Parkinson's disease and essential tremor, supporting the involvement of hereditary factors in this subset of Parkinson's disease. ${ }^{910}$ We have examined this issue by studying the occurrence of Parkinson's disease and essential tremor in parents and siblings of early-onset Parkinsonian patients. Address for reprint requests: Dr R J Martila, Department of
Neurology, University of Turku, SF-20520 Turku, Finland.

Received 28 July 1987 and in revised form 29 September 1987. Accepted 1 October 1987

\section{Patients and methods}

Fifty-two patients suffering from idiopathic Parkinson's disease with onset before the age of 45 years who were regularly followed up at our department were included in this study. The diagnostic criteria included the presence of rest tremor, rigidity and hypokinesia and absence of previous neuroleptic treatment and of atypical features such as signs of pyramidal lesions, apractic gait, cerebellar symptoms, prominent postural or intention tremor, involuntary movements other than rest tremor, profound autonomic failure or prominent dementia. Additionally, in most patients serum copper and ceruloplasmin determinations were made. All the patients had beneficial response to levodopa treatment. There were 22 women and 30 men. The mean age at onset was 39.9 (SD 4.5 years). At the time of the study, the mean duration of Parkinson's disease was 14.7 (SD 7.4) years, and the mean age of the patients was 53.7 (SD 8.0) years. The patients responded to a detailed questionnaire about the size of their family and the occurrence of Parkinson's disease or essential tremor in their parents and siblings. The medical records of allegedly affected relatives were collected. This was possible in every case with suspected Parkinson's disease, but only in two cases of relatives with tremor alone. The numbers and ages of parents and siblings are given in table 1 . The expected numbers of cases with Parkinson's disease or essential tremor among the relatives were calculated according to age and sex specific incidence rates for Parkinson's disease and for essential tremor respectively obtained in two Finnish epidemiological studies. ${ }^{1112}$ The observed and expected incidences (cases per person-years observed) were compared using the normal approximation to binomial distribution $\left(z-\right.$ test $\left.^{13}\right)$. 
Table 1 Parents and siblings

\begin{tabular}{|c|c|c|c|c|c|c|c|}
\hline & Number & Number alive* & Mean age* & $S D$ & Number dead & $\begin{array}{l}\text { Mean age } \\
\text { at death }\end{array}$ & $S D$ \\
\hline $\begin{array}{l}\text { Mothers } \\
\text { Fathers } \\
\text { Sisters } \\
\text { Brothers }\end{array}$ & $\begin{array}{r}52 \\
52 \\
116 \\
116\end{array}$ & $\begin{array}{r}7 \\
4 \\
100 \\
88\end{array}$ & $\begin{array}{l}76 \cdot 4 \\
62 \cdot 0 \\
55 \cdot 2 \\
54 \cdot 3\end{array}$ & $\begin{array}{r}11.5 \\
6.9 \\
10.7 \\
11.6\end{array}$ & $\begin{array}{l}45 \\
48 \\
16 \\
28\end{array}$ & $\begin{array}{l}70.5 \\
66.8 \\
33.7 \\
29.5\end{array}$ & $\begin{array}{l}11.8 \\
13.4 \\
26.4 \\
24.0\end{array}$ \\
\hline
\end{tabular}

*December 31, 1983

Table 2 Parkinson's disease and essential tremor in parents and siblings of early-onset Parkinsonian patients

\begin{tabular}{|c|c|c|c|c|c|}
\hline & \multirow{2}{*}{$\begin{array}{l}\text { Person-years } \\
\text { observed }\end{array}$} & \multicolumn{2}{|c|}{ Parkinson's disease $†$} & \multicolumn{2}{|l|}{ Essential tremort } \\
\hline & & Number observed & Number expected & Number observed & Number expected \\
\hline $\begin{array}{l}\text { Parents } \\
\text { Siblings } \\
\text { Total }\end{array}$ & $\begin{array}{l}3009 \\
3404 \\
6413\end{array}$ & $\begin{array}{l}1(0.33) \\
2(0.59) \\
3(0.47)\end{array}$ & $\begin{array}{l}1.2(0.40) \\
0.7(0.21) \\
1.9(0.30)\end{array}$ & $\begin{array}{r}10(3.32) \\
3(0 \cdot 88) \\
13(2 \cdot 03)\end{array}$ & $\begin{array}{r}5.4(1.79) \\
5.3(1.56) \\
10.7(1.67)\end{array}$ \\
\hline
\end{tabular}

*Between the age of 40 years and 31 December 1983, or death.

tThere are no significant differences between observed and expected incidences (z-test).

( ) Incidence per 1000 person-years.

\section{Results}

A total of 19093 person-years were observed, 7169 in the parents and 11924 in the siblings. There were altogether three cases of Parkinson's disease among the relatives: one case in the parents and two cases in the siblings. Tremor characteristic of essential tremor occurred or had occurred in 10 parents and in three siblings. The observed incidence for Parkinson's disease or essential tremor did not differ significantly from the relevant expected incidence in any group (table 2).

\section{Discussion}

Studying the familial occurrence of Parkinson's disease and essential tremor using this methodology has two main advantages. In case-control studies evaluating the presence of a certain disease in the relatives of patients and controls, the result may be substantially biased towards higher occurrence in the patient group because they have more concern about the presence of a similar disease in the family. This is clearly avoided in the present approach. A second advantage is the use of incidence figures incorporating all cases that have occurred, whether dead or alive, in a figure which can be compared with a similarly calculated expected value. However, a prerequisite for applying this type of study is the availability of appropriate incidence rates derived from populationbased epidemiological studies.

The role of the contribution of heredity to Parkinson's disease has been controversial, ${ }^{1}$ until a very low concordance for Parkinson's disease in monozygotic
Table 3 Association of Parkinson's disease and essential tremor. Summary of studies

\begin{tabular}{|c|c|c|}
\hline Author & Type of study & Observation \\
\hline $\begin{array}{l}\text { Larsson and Sjögren } 1960^{15} \\
\text { Duvoisin et al. } 1969^{3} \\
\text { Hornabrook and } \\
\text { Nagurney } 1976^{16} \\
\text { Marttila and Rinne } 1976^{5} \\
\text { Roy et al. } 1983^{10} \\
\text { Marttila et al. } 1984^{17} \\
\text { Rajput et al. } 1984^{18} \\
\text { Geraghty et al. } 1985^{19} \\
\text { Lang et al. } 1986^{20} \\
\text { Findley et al. } 1987^{21}\end{array}$ & $\begin{array}{l}\text { Epidemiological } \\
\text { Clinical series } \\
\text { Epidemiological } \\
\text { Epidemiological } \\
\text { Clinical series } \\
\text { Epidemiological } \\
\text { Epidemiological } \\
\text { Clinical series } \\
\text { Clinical series } \\
\text { Clinical series }\end{array}$ & $\begin{array}{l}\text { No association } \\
\text { No association } \\
\text { Possible } \\
\text { association } \\
\text { No association } \\
\text { Positive } \\
\text { association } \\
\text { No association } \\
\text { No association } \\
\text { Positive } \\
\text { association } \\
\text { Possible } \\
\text { association } \\
\text { No association }\end{array}$ \\
\hline
\end{tabular}

twins was consistently observed in three studies, ${ }^{6-8}$ indicating that the role of heredity in the development of Parkinson's disease is negligible. However, it has been suggested that early-onset (before the age of 40 years) Parkinson's disease might behave differently, relating to a genetic background. ${ }^{910}$ In another study, however, a low familial prevalence of Parkinson's disease and tremor was observed in patients with onset after the age of 25 and before the age of 40 years, whereas patients with onset before 25 years had high familial occurrence of Parkinsonism and probably suffered from some disease other than idiopathic Parkinson's disease. ${ }^{14}$ This finding is supported by our present results which suggest that early-onset Parkinson's disease is no different in terms of the involvement of heredity from Parkinson's disease occurring with onset at later ages. 
The association of Parkinson's disease and essential tremor has been subject to several different kinds of studies (table 3). Most of the studies in which an association has been found have analysed clinical series, often susceptible to selection bias. Neither epidemiological approaches, nor a number of other clinical studies, on the other hand, have demonstrated anything more than a chance association of Parkinson's disease and essential tremor. The present study further substantiates the absence of a specific association, and indicates that even early-onset Parkinson's disease appears to have no specific connections with essential tremor.

\section{References}

1 Duvoisin RC. The cause of Parkinson's disease. In: Marsden CD, Fahn S, eds. Movement Disorders. London: Butterworth, 1982;8-24.

2 Marttila RJ, Rinne UK. Epidemiology of Parkinson's disease. In: Poeck K, Freund HJ, Gänshirt H, eds. Neurology. Heidelberg: Springer Verlag, 1986;180-90.

3 Duvoisin RC, Grearing FR, Schweitzer MD, Yahr MD. A family study of parkinsonism. In: Barbeau A, Brunette JR, eds. Progress in Neurogenetics. International Congress Series No. 175, Vol. 1. Amsterdam: Excerpta Medica, 1969;492-6.

4 Martin WE, Young WI, Anderson VE. Parkinson's disease. A genetic study. Brain 1973;96:495-506.

5 Marttila RJ, Rinne UK. Arteriosclerosis, heredity, and some previous infections in the etiology of Parkinson's disease. A case-control study. Clin Neurol Neurosurg 1976;79:46-56.

6 Ward CD, Duvoisin RC, Ince SE, Nutt JD, Eldridge R, Calne DB. Parkinson's disease in 65 pairs of twins and in a set of quadruplets. Neurology 1983;33:815-24.
7 Marsden CD. Parkinson's disease in twins. J Neurol Neurosurg Psychiatry 1986;50:105-6.

8 Marttila RJ, Kaprio J, Koskenvuo M, Rinne UK. Finnish Parkinson's disease twin study: preliminary results. Uppsala $J$ Med Sci 1986;suppl 43:93.

9 Barbeau A, Pourcher E. New data on the genetics of Parkinson's disease. Can J Neurol Sci 1982;9:53-60.

10 Roy M, Boyer L, Barbeau A. A prospective study of 50 cases of familial Parkinson's disease. Can J Neurol Sci 1983;10:37-42.

11 Marttila RJ, Rinne UK. Epidemiology of Parkinson's disease in Finland. Acta Neurol Scand 1976;53:81-102.

12 Rautakorpi I. Essential Tremor. An epidemiological, clinical and genetic study. Doctoral thesis., Turku 1978.

13 Kleinbaum DG, Kupper LL, Morgenstern H. Epidemiologic Research. Principles and Quantitative Methods. New York: Van Nostrand Reinhold, 1982.

14 Quinn NP, Critchley P, Marsden CD. Young-onset parkinsonism. Movement Disorders 1987;2:73-91.

15 Larsson T, Sjögren T. Essential tremor. A clinical and genetic population study. Acta Psychiat Neurol Scand 1960;suppl. 144:1-176.

16 Hornabrook RW, Nagurney JT. Essential tremor in Papua, New Guinea. Brain 1976;99:654-72.

17 Marttila RJ, Rautakorpi I, Rinne UK. The relation of essential tremor to Parkinson's disease. J Neurol Neurosurg Psychiatry 1984;47:734-5.

18 Rajput AH, Offord KP, Beard CM, Kurland LT. Essential tremor in Rochester, Minnesota: A 45-year study. J Neurol Neurosurg Psychiatry 1984;47:466-70.

19 Geraghty JJ, Jankovic JJ, Zetusky WJ. Association between essential tremor and Parkinson's disease. Ann Neurol 1985; 17:329-33.

20 Lang AE, Kierans C, Blair RDG. Family history of tremor in Parkinson's disease compared with those of controls and patients with idiopathic dystonia. Adv Neurol 1987;45:313-6.

21 Findley L, Cleeves L, Koller W. Is there a relationship between essential tremor and Parkinson's disease? Neurology 1987;37 (suppl.1):122. 